\title{
PROXIMATE COMPOSITION, STRUCTURAL CHARACTERIZATION AND PHYTOCHEMICAL SCREENING OF THE SEED OIL OF ADENANTHERA PAVONINA LINN
}

\author{
Taiwo F. Owoeye ${ }^{1, *}$, Olayinka Oyewale Ajani ${ }^{1}$, Deborah K. Akinlabu ${ }^{2}$ \\ and Opeyemi I. Ayanda ${ }^{2}$ \\ ${ }^{1}$ Department of Chemistry, Covenant University, CST, Canaanland, Km 10 Idiroko Road, P.M.B. \\ 1023, Ota, Ogun State, Nigeria. \\ ${ }^{2}$ Department of Biological Sciences, Covenant University, CST, Canaanland, Km 10 Idiroko \\ Road, P.M.B. 1023, Ota, Ogun State, Nigeria. \\ *E-Mail: felicia.owoeye@ covenantuniversity.edu.ng
}

\begin{abstract}
Adenanthera pavonina is leguminous species which is a perennial and non-climbing tree which is a highly valuable plant for food, drink, and traditional medicine. The Adenanthera pavonina Linn Seed was obtained in our institution premises. This present study was targeted at evaluating proximate analysis, phytochemical determination, a physicochemical parameter of the spectroscopically characterized oil sample of Adenanthera pavonina. The oil which was extracted by standard method had percentage yield of $15.36 \%$. The phytochemical screening of the oil revealed the presence of saponin, alkaloid, and terpenoids. Proximate analysis result unveiled that seed oil of Adenanthera pavonina Linn had an appreciable quantity of protein $27.72 \%$, Crude fiber 5.82 and Ash contents 2.51 . It also showed the moisture content, organic matter, carbohydrate, $\mathrm{pH}$ and Refractive index to be $13.34 \%, 97.49 \%$ $54.36 \%, 5.96$ and 1.62 respectively. The mineral determination showed that the seed oil contained Manganese $(0.001 \pm 0.0002 \%)$, Iron (13.52 mg/kg), while Potassium (K), Sodium (Na), Nickel (Ni), Chromium (Cr), Cobalt $(\mathrm{Co})$, Lead $(\mathrm{Pb})$ and Cadmium $(\mathrm{Cd})$ were below the detectable limit. The structure of the oil was elucidated using physicochemical analyses and spectral data which include FT-IR, UV, ${ }^{1} \mathrm{H}-$ and ${ }^{13} \mathrm{C}-\mathrm{NMR}$ as well as mass spectral data. The spectroscopic data correlated well and was consistent with the proposed structure. The seed oil could provide access to increase dietary formulation owing to its high protein content.

Keywords: oxidative rancidity, soxhlet extraction, phytochemistry, Adenanthera pavonina
\end{abstract}

(c) RASĀYAN. All rights reserved

\section{INTRODUCTION}

Adenathera pavonina commonly known as a red-bead tree is a fast-growing tree included in the Global Compendium of Weeds as a natural and agricultural weed. ${ }^{1}$ It is usually planted in agroforestry systems to be used as a green manure, animal forage, and for soil improvement. ${ }^{2}$ This species is also used as an ornamental in gardens and urban forests. ${ }^{2}$ Physiological and phenological reports unveil that its seedling growth is slow initially and the growth becomes rapid in the second year through a fast increase in diameter and the trees are susceptible to damage in high wind. ${ }^{3}$ Among the wild seeds, those of the genus Adenathera pavonina is commonly and abundantly available in the tropical and sub-tropical region of the globe. It can be well known as optional means of dietary improvement in our ecosystem. This species is categorized food tree due to the fact that its seeds, as well as tender leaves, are being consumed by man and animal. ${ }^{4}$ The seeds are easily digested and are enjoyed by both children and adult. The bright red seed taste like soybean and its rich in protein. ${ }^{5}$ The seed, leaves, and tree of this plant are of great medicinal importance in some region of the world. A decoction of the leaves is used in the treatment of rheumatism and gout, ${ }^{6}$ while the bark is used for the treatment of leprosy. ${ }^{7}$ A decoction of the combined leaves and bark is used for the treatment of dysentery, diarrhea, and tonsillitis. ${ }^{8}$ The wood is used as tonic while the pulverized wood mixed with water is taken orally for the treatment of migraines and headaches. ${ }^{8}$ The bark 
of the tree of Adenathera pavonina is rich in saponins and can be used as soap in washing cloth and for hair shampoo. ${ }^{6}$

There are over 30,000 known edible plants, from which only 300 were domesticated accounting for more than $95 \%$ of the required human plant food. ${ }^{9}$ Insufficiency of amino acids, protein and fat in daily dietary intake among the developing countries of the world has been associated with the population explosion and they know some problems related to the increase population pressure, amino acids, fats and protein depletion of nature source in their daily diet, poverty and low agricultural production. ${ }^{4}$ This predicament has been worsen by low agricultural production and poverty as they could not meet the demand right and proportionate nutritional requirement for adequate growth and development of the populace in such areas. ${ }^{4,10}$ In the overall, the gross adverse implication of protein insufficiency is depicted in the occurrence of a diverse kind of protein calorie malnutritional diseases which include marasmus, kwashiorkor and other nutritional disorders. ${ }^{4}$ In view of this prevalent challenges, it is conceivable to carefully explore the nutritional composition of under-utilized seed oil to improve the food profile and status of the nation. Thus, this research work aimed at obtaining knowledge and relevance scientific information on the physicochemical parameters of oil and to investigate the nutritional quality and phytochemical constituents profiling data on the characterized Adenanthera pavonina seed oil so as to identify its nutraceutical potential for human consumption and livestock feed meal production.

\section{General Condition}

\section{EXPERIMENTAL}

The IR of the oil sample was run in $\mathrm{KBr}$ pellet using Bruker FT-IR spectrophotometer while the UV of the sample was run in $n$-hexane using Genesys 10uv Spectrophotometer while the boiling point was determined using boiling point apparatus. The metal content determination was carried out with AAS Spectrometer-S Series 712354V1-27 while the refractive index was determined using Refractometer with model no 700162 and ultraviolet irradiation at 254 and $360 \mathrm{~nm}$ was used for detection of the spot. The melting point of the crystallized oil was determined with Stuart SMP10 melting point apparatus and was uncorrected. Vecstar Furnace model ECF3 was used for ashing analysis. The seed was crushed using classic capacitor start motor milling machine B60104533. Perkin-Elmer 241 polarimeter was used to determine the optical rotatory properties whereas the moisture content was determined using moisture analyzer. The ${ }^{1} \mathrm{H}$ and ${ }^{13} \mathrm{C}$ Nuclear Magnetic Resonance were determined at $400 \mathrm{MHz}$ and $100 \mathrm{MHz}$ respectively, using JEOL Delta NMR ECX 400 spectrometer. The $\delta$ values were measured in ppm with respect to tetramethylsilane (TMS) as the internal standard using $\mathrm{CDCl}_{3}$ solvent. After extraction was completed, the solvent was removed at low pressure using IKA® RV 10 Rotary evaporator.

\section{Seed Sample Collection}

Adenanthera pavonina Linn seed was harvested in the premises of our Institution described in the affiliation above in June 2016 at $27 \pm 2{ }^{\circ} \mathrm{C}$ from 6 am to 8 am as described in our earlier study. ${ }^{11}$ The fruits were mixed together from which matured and healthy ones were picked. These were then transported to the Laboratory in a polyethene bag. Authentication and identification of the plant species were carried out at the Biological Sciences Department of our institution and a voucher specimen ${ }^{11}$ was available there for reference purposes.

\section{Extraction and Isolation}

The dried seeds of Adenanthera pavonina Linn were thoroughly pulverized to increase the surface area. 2 $\mathrm{g}$ of the pulverized sample was cautiously packed in wrapped inside Whatman filter paper and mounted in a thimble for Soxhlet extraction according to our earlier description. ${ }^{11}$ Soxhlet extracted with $n$-hexane for $6 \mathrm{~h}$ duration afforded a mixture which after rotary evaporation of $n$-hexane at low pressure furnished yellow oil in $15.36 \%$ yields.

Spectral Data for the Seed Oil Sample: FT-IR (KBr): 2974 (CH aliphatic), 2822 (CH aliphatic), 2485

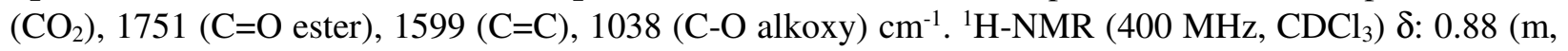


$\left.6 \mathrm{H}, 2 \times \mathrm{CH}_{3}\right), 1.24-1.29\left(\mathrm{~d}, J=12.72 \mathrm{~Hz}, 32 \mathrm{H}, \mathrm{CO}-\left(\mathbf{C H}_{2}\right)_{16}-\mathrm{CH}\right), 1.60$ (s, 3H, $\left.\mathbf{C H}_{3}-\mathrm{OCO}\right), 1.99-2.03(\mathrm{~m}$, $\left.6 \mathrm{H}, 3 \times \mathrm{CH}_{2}\right), 2.31-2.34\left(\mathrm{~m}, 4 \mathrm{H}, 2 \times \mathrm{CH}_{2}\right), 2.74-2.78\left(\mathrm{t}, J=12.72 \mathrm{~Hz}, 2 \mathrm{H}, \mathbf{C H}_{2}-\mathrm{CH}_{2}\right), 4.11-4.16\left(\mathrm{dd}, J_{1}=\right.$ $\left.5.96 \mathrm{~Hz}, J_{2}=8.00 \mathrm{~Hz}, 1 \mathrm{H}, \mathrm{CH}=\mathbf{C H}-\mathrm{CH}\right), 4.26-4.30\left(\mathrm{dd}, J_{1}=4.28 \mathrm{~Hz}, J_{2}=8.00 \mathrm{~Hz}, 1 \mathrm{H}, \mathrm{CH}-\mathbf{C H}=\mathrm{CH}\right)$, 5.30-5.36 (m, 5H). ${ }^{13} \mathrm{C}-\mathrm{NMR}\left(100 \mathrm{MHz}, \mathrm{CDCl}_{3}\right) \delta: 13.5\left(\mathrm{CH}_{3}\right), 14.2\left(\mathrm{CH}_{3}\right), 22.7\left(\mathrm{CH}_{3}\right), 24.9,25.7(3 \times$ $\left.\mathrm{CH}_{2}\right), 27.3\left(3 \times \mathrm{CH}_{2}\right), 29.2\left(2 \times \mathrm{CH}_{2}\right), 29.4\left(2 \times \mathrm{CH}_{2}\right), 29.8\left(2 \times \mathrm{CH}_{2}\right), 31.6\left(3 \times \mathrm{CH}_{2}\right), 32.0,34.1,62.2$, $68.8,127.8,130.1,130.3,172.8,173.3$ ppm. MS: in m/z (rel. \%): $508.97\left(\mathrm{M}^{+}, 34.5 \%\right), 466.95(100 \%)$, 354.37 (10.0\%), $275.00(22.5 \%), 270.03(35.0 \%)$.

\section{Phytochemical Screening Procedure}

The secondary metabolites present in the seed oil sample were chemically identified using a standard procedure we earlier described. ${ }^{12}$ The chemical tests revealed the presence of phytochemicals which include alkaloid, terpenoid steroid, and saponin.

\section{Proximate Analysis Procedure}

Micro-Kjeldahl technique was utilized for the determination of nitrogen. ${ }^{13}$ and the crude protein was derived by multiplying nitrogen percentage with a conversion factor (6.25) according to an earlier report. ${ }^{11}$ Kirk and Sawyer's method was utilized to determine the total ash while moisture, crude fiber, and crude fat were carried out by adopting the approach reported by an official method. ${ }^{14}$

\section{Determination of Total Carbohydrate}

The oil sample was determined for its total \% carbohydrate through another technique. The approach was via subtraction of the summation of crude protein, lipid, crude fiber, moisture and ash compositions from $100^{14}$. The value obtained is the percentage carbohydrate constituent of the sample.

\section{Protein and Carbohydrates Qualitative Determination}

Biuret test: The presence of protein was validated by utilizing Biuret test. To the test, the solution was added $6 \% \mathrm{NaOH}$ solution followed by few drops of $1 \% \mathrm{CuSO}_{4}$ solution. Observation of violet color confirmed that protein is present. ${ }^{15}$

\section{Molisch's Test}

Qualitative determination of carbohydrate was established using Molisch's test. To the extracted oil sample was added few drops of $\alpha$-naphthol in alcohol. Then, conc. $\mathrm{H}_{2} \mathrm{SO}_{4}(1 \mathrm{ml})$ was slowly and dropwisely added via the side wall of the test-tube. Appearance of purple coloration that turned to violet in form of a ring at the junction of the resulting mixture depicted that carbohydrate is present. ${ }^{16}$

\section{Mineral Content Analysis}

Minerals were extracted from the sample by the acid digestion method. ${ }^{12}$ The elements which include Ca, $\mathrm{Mg}, \mathrm{Zn}, \mathrm{Fe}, \mathrm{Cu}$, and $\mathrm{Mn}$ were analyzed using atomic absorption spectrometer with serial No GE71211B (S4 AA System, USA). Two metals namely K and Na were analyzed with a flame photometer (PFP7, Jenway, UK).

\section{RESULTS AND DISCUSSION}

The nutritional compositions of the diverse leguminous plant species make them the principal components of the useful daily dietary intake, ${ }^{4,17}$ for growth and total wellbeing of mankind. Adenanthera pavonina (L.) plant can be classified to be inherent to the class of Leguminosae family with subfamily name Mimossoideae. It is referred to in a various way by various people; for instance, Malaysian called it Saga, Indian called it Raktakambal, Samoa and Tango indigenes called it Lopa and English language for it are Red-Bead or Red Sandalwood. The tree belongs to the secondary forest and with an average of 20meters tall. Based on a CAGR of 20.24\%, a global market size of around Rs. 90 billion was predicted and envisaged to be achieved in 2013 regarding market values in the areas of nutraceutical and dietary supplements. ${ }^{18}$ However, this target was not met due to the challenge of food shortage. Therefore, the 
unmet gap between food supply and population growth especially in the developing countries, could be met via a continuous exploration of seed oil in the quest for novel high quality but inexpensive sources of food. Thus, this present study deals with the phytochemical constituents, physicochemical properties, proximate analysis and mineral content determination in Adenanthera Pavonina so as to investigate the nutritive value of the oil sample. The phytochemical tests were carried out for the above-named plant seed oil using the standard procedure, ${ }^{12}$ so as to ascertain the phytochemicals present in the oil and the result is as presented in Table-1. The implication of the +ve sign is to indicate the depth of the availability of such constituents. The various preliminary chemical tests in the phytochemical screening herein showed steroid to be the most abundant phytoconstituent, followed by alkaloid which occurred in moderate amount while terpenoid and saponin were present in low concentration. It is worthy to note that the two different methods of determination of alkaloid were utilized and both gave the same result. The tests were negative for tannin, flavonoid, phenol, phlabotannin, oxalate, and quinone indicating the absence of these six phytochemicals in the seed oil investigated (Table-1).

Furthermore, steroid hormones play significant roles in regulating diverse salient physiological factors in vertebrates. ${ }^{19}$ The function of steroid has received a considerable attention in reproduction and development and its enhancement of self-defense of organisms such is well documented. ${ }^{19}$ The two major work of steroids is in the alteration of membrane fluidity and activation of steroid hormone receptors. ${ }^{20}$ Regular consumption of this oil could help boosting the steroid hormones in human system which in turn help to control metabolism, inflammation, immune functions, development of sexual characteristics, osmoregulation and development of resistance against diseases and injury. Depletion of the crucial nutritive component in the consumed plant food might occur by the availability of anti-nutritional factors such as oxalates and cyanogenic glycosides. ${ }^{21}$ Thus, the absence of the oxalate in this sample is a prove of bioavailability of essential nutrients in the targeted sample reported herein.

Table-1: The phytochemical properties determination of Adenanthera pavonina Linn oil

\begin{tabular}{l|c}
\hline Phytochemical Constituent & Test Result \\
\hline Terpenoids & + \\
\hline Tannin & - \\
\hline Flavonoid & - \\
\hline Phenol & - \\
\hline Phlabotannin & - \\
\hline Carbohydrate & ++ \\
\hline Steroids & +++ \\
\hline Oxalate & - \\
\hline Alkaloid (Wagner Method) & ++ \\
\hline Alkaloid (Dragendorff Method) & ++ \\
\hline Saponin & + \\
\hline Quinone & - \\
\hline
\end{tabular}

$+++=$ highly intensed; $++=$ moderately intensed; $+=$ lowly intensed; $-=$ negative result.

It is of great importance to harness insight on the types of substances that supply energy and promote food digestibility before efficient formulation and production of market quality diets could be successfully achieved. ${ }^{11}$ Over some decades now, it is universally accepted that preventive measures against cardiovascular disorder and quality health status could be traceable to good diet intake as unveiled via diverse research findings. ${ }^{22}$ Therefore, proximate parameters were determined to ascertain the dietary usefulness $^{11}$ and the result is as shown in Table-2; the moisture content $(13.34 \pm 0.15 \%)$, the crude fibre $(5.82 \pm 0.12 \%)$, carbohydrate $(35.26 \pm 0.48 \%)$, crude fat $(15.36 \pm 0.17 \%)$, crude protein $(27.72 \pm 0.35 \%)$ and ash content $(2.51 \pm 0.08 \%)$. From the result, it was discovered that carbohydrate had the highest value, followed by crude protein, followed by crude fat, and moisture content and crude fiber in that order. The carbohydrate could be expressed as nitrogen free extract (extract) that is made up of readily digestible biomolecular components like sugar, starch, and organic acids. ${ }^{11}$ The carbohydrate that is on high side 
RASĀYAN J. Chem. Vol. 10 | No. 3 |807 - 814 | July - September | 2017

herein unveiled crucial function of the seed oil towards the improvement of man's health status. ${ }^{11}$ Although, energy supply is the main work of carbohydrate; however, diverse biochemical reaction pathways make use of carbohydrate for successful completion of the metabolic processes as reported earlier. ${ }^{11,23}$ The peristaltic movement in the alimentary canal was highly enhanced by the crude fiber intake thereby counteraction of constipation. ${ }^{24}$ Regular intake of required amount of crude fiber also helps the body to combat diverse cardiovascular diseases. ${ }^{13}$ The crude protein $(27.72 \%)$ in the seed was high. The value was in agreement with an earlier report which established the protein content of Adenanthera pavonina seed to be between 25 and 39\%.5 Therefore, protein consumption takes care of hormonal balance for repairing of the worn-out cell and aid growth via maintenance of cellular entities. Hence, from the result of the proximate profile, Adenanthera pavonina seeds had remarkable efficiency as a means of boosting the energy load of the body. The seeds of Adenanthera pavonina had $2.51 \pm 0.08 \% \mathrm{DW}$ ash which was higher than that of Guna seed $(2.18 \%)^{25}$, but lower than that of Ceiba pentandtra seed $(5.0 \%) .{ }^{26}$ The ash content of a seed may partially be a function of the soil composition on which the plants grow. ${ }^{25}$

Table-2: The proximate composition of Adenanthera pavonina Linn seed oil

\begin{tabular}{l|l}
\hline Proximate Parameter & Value (weight \%) \\
\hline Crude Protein & $27.72 \pm 0.35 \%$ \\
\hline Crude Fibre & $5.82 \pm 0.12 \%$ \\
\hline Crude Fat & $15.36 \pm 0.17 \%$ \\
\hline Ash Content & $2.51 \pm 0.08 \%$ \\
\hline Moisture Content & $13.34 \pm 0.15 \%$ \\
\hline Carbohydrate & $35.26 \pm 0.48 \%$ \\
\hline
\end{tabular}

Furthermore, the result of the physicochemical parameters was as presented in Table-3. The peroxide value P.V. (14.20 meq/kg) is a bit high and not nil as expected for fresh oil indicative of the occurrence of some levels of oxidation. Although, the oil oxidation can occur either by auto-oxidation or photooxidation, the P.V. herein might be due to the extracted oil being exposed thereby causing photooxidation. ${ }^{27}$ Also, it was not determined immediately after the extraction of the oil. FFA and acid value are 8.40 and 4.20 respectively. This implies that the refining process for such oil will be cost effective since the two parameters are low. In fact, the acid value was below the limit for oil. These are actually important variables as increase in free fatty acid is a true measure of decrease in oil quality and FFA value for consumption should be $\leq 10 .^{28}$ Factors which may lead to a high free fatty acidity in an oil sample include fungal infection, poor storage facility, seed damage during harvest, poor extraction technique among others. ${ }^{29}$ This oil is void of all these challenges due to low FFA content herein. Iodine value is $6.30 \mathrm{~g} / 100 \mathrm{~g}$; moderate iodine value shows a moderate degree of unsaturation in the sample herein. Although, the I.V. is used primarily in industry, it is of great significance to us because it gives an indication of the oil's stability and health properties. The low I.V. herein showed the presence of high amount of saturated fatty acid and low amount of unsaturated fatty acid. This is closely related to I.V. in coconut oil which is around 10. The oil compared well in I.V. with that of coconut oil which has the lowest I.V. of any dietary oil. Hence, the oil could be very resistant to oxidation and polymerization. It will make a very safe cooking oil. The refractive index (R.I.) of the sample as obtained from refractometer was 1.52. It was noticed to be a bit above the expected value from 1.476 to 1.479 as documented by ASTM standard. ${ }^{30}$ This might be associated with the availability of other entities and substances in the crude oil mixture since this parameter (R.I.) is mostly applied for the identification of a particular substance, confirm its purity, or measure its concentration. According to Maxwell's expression, the refractive index gives valuable information on permittivity and permeability ${ }^{31}$. The oil was weakly acidic with a $\mathrm{pH}$ of 5.96. This supported the fact that the oil is a mixture of organic acid and acid esters with $\mathrm{COOH}$ functionality linked to long-chain alkyl groups.

In addition, the result of the mineral content determination was obtained using atomic absorption spectrophotometric technique and the result is as shown in Table 4. From the result of mineral content 
RASĀYAN $J$. Chem.

Vol. 10 | No. 3 |807- 814 | July - September | 2017

analysis, manganese numerical value was the lowest $(0.001 \pm 0.0002 \%)$, followed by iron $(13.52 \pm 0.02$ $\mathrm{mg} / \mathrm{kg}$ ) and cholesterol content is the highest $(27.73 \pm 0.02)$, Other minerals that were below the detectable limit of the A.A.S. were potassium, sodium, nickel, chromium, cobalt, lead and cadmium. The oil seed was rich in iron with a numerical value of $13.52 \pm 0.02 \mathrm{mk} / \mathrm{kg}$; this means that regular intake of this oil and oil-riched food might lead to boosting of blood level and hemoglobin enrichment. It might help to fight anemia which is disease related to iron deficiency in the human body. It is a severe condition that pose a serious threat to the wellbeing of over one billion population globally, ${ }^{32}$ decrease work efficiency and immunity breakdown. ${ }^{33}$ Thus, regular intake of this oil might boost human chance against this deficiency. The heavy metals such as $\mathrm{Pd}$ and $\mathrm{Cd}$ were below the detectable limit which increases the chance of safety of the oil for consumption. Other mineral elements which were not detected were $\mathrm{Ni}$ and Co. The cholesterol content is $27.73 \pm 0.02 \%$. The magnesium $(0.001 \pm 0.0002 \mathrm{mg} / \mathrm{kg})$ is available in trace quantity in the test sample and it was found to fall below the required consumption limit, because an intake of up to $2 \mathrm{mg}$ to $3 \mathrm{mg}$ supply is needed per day.

Table-3: The physicochemical properties determination of Adenanthera pavonina oil

\begin{tabular}{l|l}
\hline Parameter & Value \\
\hline Free Fatty Acid (FFA) & 8.40 \\
\hline Acid Value (AV) & 4.20 \\
\hline Peroxide Value (PV) & 14.20 \\
\hline Saponification Value (SV) & 60.53 \\
\hline Iodine Value (IV) & 6.30 \\
\hline Organic Matter (OM) & $97.49 \%$ \\
\hline Refractive Index (RI) & 1.62 \\
\hline Boiling Point (BP) & $258^{\circ} \mathrm{C}$ \\
\hline Density & $0.85 \mathrm{~g} / \mathrm{ml}$ \\
\hline Melting Point (MP) & $126^{\circ} \mathrm{C}$ \\
\hline pH & 5.96 \\
\hline Cloud Point (CP) & $0.60{ }^{\circ} \mathrm{C}$ \\
\hline
\end{tabular}

Table-4: The mineral composition evaluation of Adenanthera pavonina seed oil

\begin{tabular}{l|l}
\hline Mineral Constituent & Test Result \\
\hline Potassium (K in \%) & BDL \\
\hline Sodium $(\mathrm{Na}$ in \%) & BDL \\
\hline Manganese (Mn in \%) & $0.001 \quad \pm$ \\
& 0.0002 \\
\hline Iron $(\mathrm{Fe}$ in $\mathrm{mg} / \mathrm{kg})$ & $13.52 \pm 0.02$ \\
\hline Nickel $(\mathrm{Ni}$ in $\mathrm{mk} / \mathrm{kg})$ & BDL \\
\hline Chromium $(\mathrm{Cr} \mathrm{in} \mathrm{mk/kg)}$ & BDL \\
\hline Cobalt $(\mathrm{Co}$ in $\mathrm{mg} / \mathrm{kg})$ & BDL \\
\hline Lead $(\mathrm{Pb}$ in $\mathrm{mg} / \mathrm{kg})$ & BDL \\
\hline Cadmium $(\mathrm{Cd}$ in $\mathrm{mg} / \mathrm{kg})$ & BDL \\
\hline Cholesterol (in \%) & $27.73 \pm 0.02$ \\
\hline
\end{tabular}

Values are mean \pm SD of triplicate determination. $\mathrm{BDL}=$ Below Detectable Limit.

The spectroscopic study of the oil sample was carried out using FT-IR, UV-visible, ${ }^{1} \mathrm{H}$ - and ${ }^{13} \mathrm{C}-\mathrm{NMR}$ spectral data. The ${ }^{1} \mathrm{H}-\mathrm{NMR}$ and ${ }^{13} \mathrm{C}-\mathrm{NMR}$ spectra of the oil was run using $\mathrm{CDCl}_{3}$ at machine capacity of $400 \mathrm{MHz}$ and $100 \mathrm{MHz}$ respectively. The signal was found downfield below $\delta 6.00 \mathrm{ppm}$, implied the absence of an aromatic ring. The most down field signal was a $5 \mathrm{H}$ multiplet at $\delta 5.30-5.36 \mathrm{ppm}$, after which was dd at chemical shift value of $4.26-4.30\left(J_{1}=4.28 \mathrm{~Hz}, J_{2}=8.00 \mathrm{~Hz}\right)$ which was $1 \mathrm{H}$ of $\mathrm{C}=\mathrm{C}$ 
whose neighbor $1 \mathrm{H}$ of $\mathrm{C}=\mathrm{C}$ was observed as a dd at chemical shift value 4.11-4.16 $\left(J_{1}=5.96 \mathrm{~Hz}, J_{2}=\right.$ $8.00 \mathrm{~Hz}$ ). All other signals were found up-field from $\delta 2.74-2.78 \mathrm{ppm}$ to $\delta 0.88 \mathrm{ppm}$. According to ${ }^{13} \mathrm{C}$ NMR spectral data at $100 \mathrm{MHz}$, the $\mathrm{C}=\mathrm{O}$ of ester was found as the most downfield signals at $\delta 173.3$ and $172.8 \mathrm{ppm}$ and it was in concordance with the previously documented value; ${ }^{11,34}$ while $\mathrm{CH}_{3}$ carbon resonated as the most upfield one at $\delta 13.5 \mathrm{ppm}$ with respect to TMS. Findings from IR study showed the presence of C-H aliphatic at $2974 \mathrm{~cm}^{-1}$ and $2822 \mathrm{~cm}^{-1}$. The carbonyl of fatty acid ester was responsible for the band at $1751 \mathrm{~cm}^{-1}$ and it was authenticated via the appearance of $\mathrm{C}-\mathrm{O}$ alkoxide at $1038 \mathrm{~cm}^{-1}$ which was consistent with earlier reported value for $\mathrm{C}=\mathrm{O}$ ester and $\mathrm{C}-\mathrm{O}$ of its alkoxide. ${ }^{35}$ The $\mathrm{C}=\mathrm{C}$ functionality was depicted at $1599 \mathrm{~cm}^{-1}$ while $\mathrm{CH}_{2}$ (deformation) band was noticed at $1461 \mathrm{~cm}^{-1}$. The UV spectrum of the targeted sample of Adenanthera pavonina was run in $n$-hexane using single beam Genesys 10uv spectrophotometer (Table-5). A baseline was generated using $n$-hexane as the blank. The absorbance was recorded at the wavelength and the $\log \varepsilon_{\max }$ was determined using Beer-Lambert law. The most prominent absorbance (1.665) was noticed for the wavelength $\lambda_{\max }$ of $199 \mathrm{~nm}\left(\log \varepsilon_{\max } 5.22\right)$. This was below 200 $\mathrm{nm}$ indicating the presence of some levels of saturation and absence of benzenoid. Other peaks were observed at lower absorbance levels of $0.7011,0.5809$ and 0.2525 giving rise to the wavelength values of $210 \mathrm{~nm}\left(\log \varepsilon_{\max } 4.85\right), 229 \mathrm{~nm}\left(\log \varepsilon_{\max } 4.76\right)$ and $277 \mathrm{~nm}\left(\log \varepsilon_{\max } 4.40\right)$ respectively might be as a result of the presence of auxochromic groups which through the delocalization of the lone pairs caused bathochromic shift in the wavelength values.

Table-5: UV-Visible Spectral Result of Oil of Adenanthera pavonina Linn in $n$-Hexane

\begin{tabular}{l|lccc}
\hline Wavelength $\left(\lambda_{\max }\right.$ in $\left.\mathrm{nm}\right)$ & 199.00 & 210.00 & 229.00 & 277.00 \\
\hline Absorbance & 1.665 & 0.7011 & 0.5809 & 0.2525 \\
\hline Molar Absorptivity $\left(\varepsilon_{\max }\right.$ in M $\left.^{-1} \mathrm{dm}^{-1}\right)$ & 166,500 & 70,110 & 58,090 & 25,250 \\
\hline Log of Molar Absorp. $\left(\log \varepsilon_{\max }\right)$ & 5.22 & 4.85 & 4.76 & 4.40 \\
\hline
\end{tabular}

\section{CONCLUSION}

The seed oil of Adenanthera pavonina linn Seeds has been successfully analyzed and characterized using spectroscopic means which include, FT-IR, UV-visible, ${ }^{1} \mathrm{H}$ - and ${ }^{13} \mathrm{C}-\mathrm{NMR}$ spectral data. The oil was evaluated for the presence of secondary metabolites (phytochemicals), the proximate analytical determination as well as mineral content. Diverse standard scientific approaches have been successfully utilized to gather the array of data reported herein. From the outcome of this study, it is quite evident that the oil sample investigated might be a potential replacement for some common edible oil. The oil of Adenanthera pavonina linn Seed is a good candidate for further study in term of the antimicrobial evaluation in order to identify its pharmaceutical efficacy for nutraceutical benefits.

\section{ACKNOWLEDGEMENT}

All authors gratefully acknowledge Covenant University for the support for this work. OOA is thankful to The World Academy of Sciences for the sponsorship of this project under the TWAS Research Grants Programme in Basic Sciences for Individual Scientists (Grant No. 14-069 RG/CHE/AF/AC_1).

\section{REFERENCES}

1. R.P. Randall, A Global Compendium of Weeds, $2^{\text {nd }}$ Edition, Department of Agriculture and Food, Western Australia, p. 1124 (2012).

2. A. Praciak, CABI Encyclopedia of Forest Trees, Wallingford Ltd., UK, p. 41 (2013)

3. O.A. Olajide, C.A. Echianu, A.D. Adedapo and J.M. Makinde, Inflammopharmacology, 12(2), 196 (2004).

4. K.P. Senga, O.D. Opota, V.A. Tamba, L.G. Tona, K.O. Kambu, A. Covaci, S. Apers, L. Pieters and K.R. Cimanga, Int. J. PharmTech. Res., 5(1), 205 (2013).

5. S. Facciola, Cornucopia II: A Source Book of Edible Plants, $2^{\text {nd }}$ Edition, Kampong Publications, California, p. 299 (1998). 
RASĀYAN J. Chem.

Vol. 10 | No. 3 |807- 814 | July - September | 2017

6. M. Barwick and A. van der Shan, Tropical and subtropical trees - A Worldwide Encyclopedia Guide. Thames and Hudson Publishers, London, p.212 (2004).

7. R.B. Pandhare, B. Sangameswaran, P.B. MoHITE, and S.G. Khanage, Revista Brasileira de Farmacognosia, 22(2), 428 (2012).

8. R. Sultana and T. Gulzar, J. Am. Oil Chem. Soc., 89, 1611 (2012).

9. J.R. Tabuti, S.S. Dhillion, and K.A. Lye, Int. J. Food Sci. Nutr., 55, 485 (2004).

10. V. Aletor, and O.O. Aladetimi, Nahrung., 33(10), 999 (1989).

11. O.O. Ajani, T.F. Owoeye, G.I. Olasehinde, O.Y. Audu, F.E. Owolabi, D.K. Akinlabu and A. EdoborOsoh, Am. J. Food Tech., 11(6), 253 (2016).

12. O.O. Ajani, T.F. Owoeye, G.I. Olasehinde, D.K. Akinlabu, F.E. Owolabi and O.Y. Audu, J. Biol. Sci., 16(4), 102 (2016).

13. D. Pearson, Chemical Analysis of Food, $7^{\text {th }}$ Edition, Churchill, London, p. 7 (1979).

14. AOAC, Association of Official Analytical Chemists, $21^{\text {st }}$ Edition, AOCS Press, Washington D.C. USA, 46 (1999).

15. V. Suneetha, M. Bishwambhar, R. Gopinath, S.R. Shrestha, G.K.B. Kartik, C. Pravesh, C. Apoorvi and R. Kalyani, Asian J. Microbiol. Biotech. Environ. Sci., 14, 405 (2012).

16. A. Gangwal, S.K. Parmar, and N.R. Sheth, Der Pharm. Lett., 2, 307 (2010).

17. K.J. Umar, L.G. Hassan, H. Usman, and R.S.U. Wasagu, Pak. J. Biol. Sci., 16, 536 (2013).

18. J. Bernal, J.A. Mendiola, E. Lbáñez and A. Cifuentes, J. Pharm. Biomed. Anal., 55(4), 758 (2010).

19. B.B. Clayton, and R.H. Kluger, 2008, Steroid in: R. McHenry and D. Holberg (Eds.), Encyclopedia Britannica $15^{\text {th }}$ Edition, Encyclopædia Britannica Inc., UK.

20. B.B.P. Gupta and K. Lalchhandama, Curr. Sci., 83(9), 1103 (2002).

21. A.A. Akindahunsi, and S.O. Salawu, Afr. J. Biotech., 4, 497 (2005).

22. O.E. Oyewole, and T. Atinmo, Afr. J. Med. Med. Sci., 37, 219 (2008).

23. S. Bhattacharjee, A. Sultana, M.H. Sazzad, M.A. Islam, M.M. Athashom and Asaduzzaman, Int. J. Nutr. Food Sci., 2(5), 246 (2013).

24. S. Ponnusamy, and T. Vellaichamy, J. Appl. Pharm. Sci., 2(5), 106 (2012).

25. C.Y. Maina, and H.M. Aliyu, Int. J. Food Agric. Res., 6, 93 (2009).

26. L.G. Hassan, M.A. Sokoto, S.M. Dangogo and M.J. Ladan, Afr. J. Nat. Sci., 9, 11 (2006).

27. A.P. Kiritsakis A.K. Kiritsakis, E.B. Lenart, W.C. Willet and R.J. Hernandez, Olive Oil: From the Tree to the Table. $2^{\text {nd }}$ Edition, Wiley Black-Well, USA 121 (2006).

28. A.E. Balley, Industrial Oil and Fat Product, $3^{\text {rd }}$ Edition, John Wiley-Interscience, New York, USA (1982).I

29. M.P. Canizares-Macias, J.A. Garcia-Mesa and M.D.L. de Castro, Anal. Chim. Acta, 502, 161 (2004).

30. ASTM International, Annual Book of Standards, section 12.10, ASTM International, West Conshohocken, p. 734 (2002).

31. F. Koohyar, J. Thermodyn. Catal., 4, e117 (2013).

32. F. Trowbridge and M. Martorell, J. Nutri., 85, 875 (2002).

33. B.J. Cherayil, Immunol. Res., 50(1), 1 (2011).

34. A. Al-Kawkabani, B. Boutemeur-Kheddis, M. Makhloufi-Chebli, M. Hamdi, O. Talhi, and A.M.S. Silva, Tetrahedron Lett., 54, 5111 (2013).

35. O.O. Ajani, O. Ajayi, J.A. Adekoya, T.F. Owoeye, B.M. Durodola and O.M. Ogunleye, J. Appl. Sci., 16(3), 77 (2016).

[RJC-1712/2017] 